\title{
An Eighteenth Century Budget
}

THE budget in all its forms is attracting so much attention at the present time that we are inclined to think of it as exclusively a twentieth century institution. A small pamphlet belonging to the Business Library, however, is evidence that it had its origin at least as long ago as 1744. This very early example of a family budget, "An Estimate of the necessary Charge of a Family in the middling Station of Life, consisting of a Man, his Wife, Four Children, and One Maid-servant," occurs in a pamphlet interesting in itself, being "An Apology for the Business of Pawn-Broking, By a Pawn-Broker." The Pawn-Broker makes out a very good case for his pilloried and despised trade. He gives statistics to prove that he and his confreres could not afford to stay in business and charge any less than their accustomed rate of interest, taking into consideration the time consumed in the transacting of so many small loans, the necessity of employing two assistants, and the interest his money would produce out of trade. Besides the expenses of carrying on business, says he, the broker "may find it convenient or necessary to marry," and he demands with Shylock whether a pawn-broker's family can live without food and raiment more than other people, or whether his children must not be "fed, cloathed, educated, and put out into the World, as well as those of other Men?"

He demonstrates that his trade does not average an interest of more than eighteen per cent per annum, an income less than the annual percentage made by most shopkeepers on their capital. He answers the charge of the shopkeepers that a pawn-broker is not a fair trader by maintaining that he fills an economic want at the smallest practicable charge.

As an illustration of the reasonableness of his charges, considering the expenses he has to meet, the writer quotes from the Essay on Trade of a contemporary merchant, who has compiled a budget for a middle-class tradesman's family in London. The budget is reproduced in facsimile herewith. The bill of fare includes bread, butter, cheese, "fish and flesh meat," mustard, pickles, tea, and other groceries, and "milk, one day with another," but seems to be weak in vitamines, unless we take "roots and herbs" to mean green vegetables. The family expenses include some items that do not appear in our budgets, like "ten-shilling small beer, a firkin 
An Es T I M A T 8 of the neceffary Charge of a Family in the middling Station of Life, confifting of a Man, his Wife, Four Children, and One Maid-fervant.

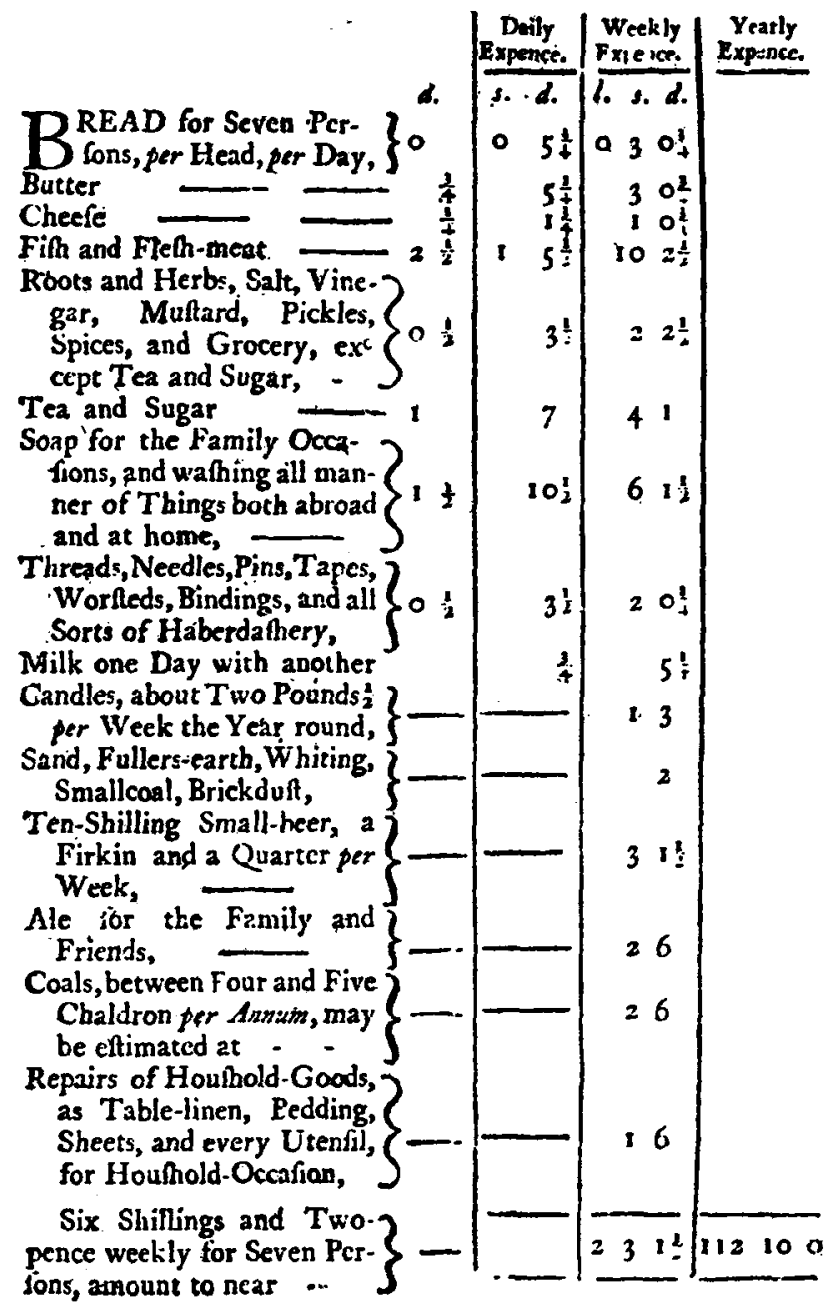




\section{Drought over s. $d$.}

Cloaths of all kinds for the Malter of the tamily $\quad 16$

Cloaths for Wife, who can't wear much, nor very
fine Laces, with

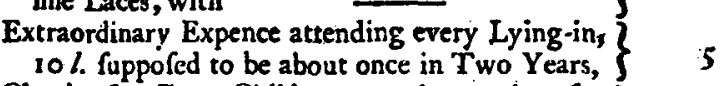

Cloaths for Four Children, at 7 l. per Ann. for
each Child,

Schooling for Four Children, including every

Charge thereunto relating fuppoled to be equal, $\$ 8$

at least, to 10 s. per Quarter for each Child, 'S

The Maid's Wages may be 4 to

Pocket-Expences for the Mafter of the Family, $\}$ to 8
fuppofed to be about 4 s. per. Week,

For the Mifters of the Family, and for the Four? Children, to buy Fruit, Toys, Esc. at a s.per $\} \quad 54$

Entertainments in Retum for fuch Favours from ? Friends and Relations,

Phyfic for the whole Family one Year with another, and the extraordinary Expence arifing $\}$ by Illnefs, may exceed

A Country-Lodging foinetimes, for the Health and Recreation of the Family; or, inftead thereof, the extraordinary Charge of nurfing a Child abroad 3 which, in fuch a Family, is often needful,

Shaving, 7 s. $6 \mathrm{~d}$. per Quarter; and Cleaning Shoes, 2 s. 6 d.per Quarter,

Rent and Taxes may be fomewhat more or lefs than

Expences of Trade with Cuffomers, Traveiling-? Charges, Chriftmas-box Money, Poltage of Letters, Esc. for the fake of even Money, at leaft,

Bad Debts, which may eafily be more than 21.3 per Cent. on the tuppofed Capital of $1000 \mathrm{l}$.

There muft be laid up one Year with another, for Twenty Years, in order to leave each Child, and a Widow, if there thould be one, 500 l. apiece,

One 1000 l. therefore, by this Eftimate, fhould ? gain, one Year with another, 
and a quarter per week," and ale for the family and friends. The wife "can't wear much nor very fine laces with I6. s. a week for cloaths," but the family expects to have a country lodging sometimes for its rest and recreation, and to employ a maid servant. The pocket expenses of the master are Io pounds 8 shillings a year, and 5 pounds 4 shillings do for the mistress and for the four children to buy fruit, toys etc. Schooling for the children amounts to 8 pounds annually, at least, and "entertainments in return for such favors from friends and relations" to 4 pounds. Their 390 pounds must also cover expenses of trade, travelling charges, and the like; but even so, the standard of living in the middling station of life in the City of London in the eighteen th century seems to have provided for a fairly comfortable and well-rounded existence.

\section{"An Historical, Geographical, Commercial and Philosophical View" of the Americas}

Four volumes of this comprehensive view of the Western Hemisphere, written in 1795 by an English dissenting minister, are among the many curious items which are continually being added to the collection of the Society. They derive peculiar interest from the fact that the author, William Winterbotham, at the time it was written was a prisoner in Newgate, to which he had been committed for expressing too liberal views in his sermons. The work is a compilation, and he quotes Benjamin Franklin and Buffon among his authorities. Winterbotham was a close friend of Southey, and the latter left his manuscript of William Tell with him in prison.

The first volume begins with the discovery of America, and after a very fair-minded account of the Revolution, the author proceeds with a description of North, Central, and South America, and the West Indies. Two cuts from the section on American quadrupeds are reproduced on the next page.

Along with the dissimilarities to be expected between this and later books on the same subject, in the matter described and the manner of expression, there are some amusing resemblances to the modern point of view. One section, entitled "Prospects and Advantages of European Settlers," begins with an effort to disabuse the minds of prospective immigrants of some mistaken 